\title{
Обратная конверсия типа проводимости ГЭС КРТ МЛЭ после плазмохимического травления при пониженной температуре
}

\author{
Д.В. Горшков, В.С.Варавин, Г.Ю. Сидоров, В.Г. Ремесник, И.В. Сабинина \\ Институт физики полупроводников им. А.В. Ржанова СО РАН, \\ Новосибирск, 630090, пр. Ак. Лаврентьева, 13 \\ тел: (383)330-89-60, факс: (383)333-27-71, эл. почта: GorshkovDV@isp.nsc.ru
}

DOI 10.34077/RCSP2019-48

Для уменьшения размера пикселя и создания мультиспектрального матричного приёмника инфракрасного излучения на основе ГЭС КРТ МЛЭ необходимо анизотропное травление с высоким соотношением глубины к ширине канавки травления. Для многих материалов плазмохимическое травление показывает хороший результат. В случае КРТ имеется недостаток в виде конверсии материала р-типа на некоторую глубину в $\mathrm{n}$-тип и образование приповерхностного тонкого слоя $\mathrm{n}+-$ типа. В данной работе найден режим травления, при котором наблюдалась релаксация параметров nслоя, образовавшегося у поверхности после плазмохимического травления, и обратная конверсия к исходному р-типу проводимости КРТ.

Эксперименты проводились на образцах ГЭС КРТ МЛЭ с составом $\mathrm{x}=0,22$, вакансионного р-типа проводимости с концентрацией дырок $\approx 10^{16} \mathrm{~cm}^{-3}$. Плазмохимическое травление проводилось на установке с генератором индуктивно-связанной плазмы в газовой смеси $\mathrm{CH}_{4}$ и $\mathrm{Ar}$. Температура образца на протяжении травления поддерживалась равной $-65^{\circ} \mathrm{C}$. Скорость травления составила 50 нм/мин. На образцах измерялись магнетополевые зависимости проводимости и коэффициента Холла $\mathrm{R}_{\mathrm{H}}$ методом Ван-дер-Пау, при $77 \mathrm{~K}$. Измеренные магнетополевые зависимости $\mathrm{R}_{\mathrm{H}}$ при разных временах хранения образца при комнатной температуре представлена на рисунке. Сразу после травления наблюдается конверсия р-типа проводимости в $\mathrm{n}$-тип. С помощью послойного травления было установлено, что толщина области n-типа не превышает 1 мкм и основная часть электронов сосредоточена вблизи поверхности с концентрацией электронов около $10^{16} \mathrm{~cm}^{-3}$. При увеличении времени хранения образца при комнатной температуре наблюдается уменьшение концентрации и

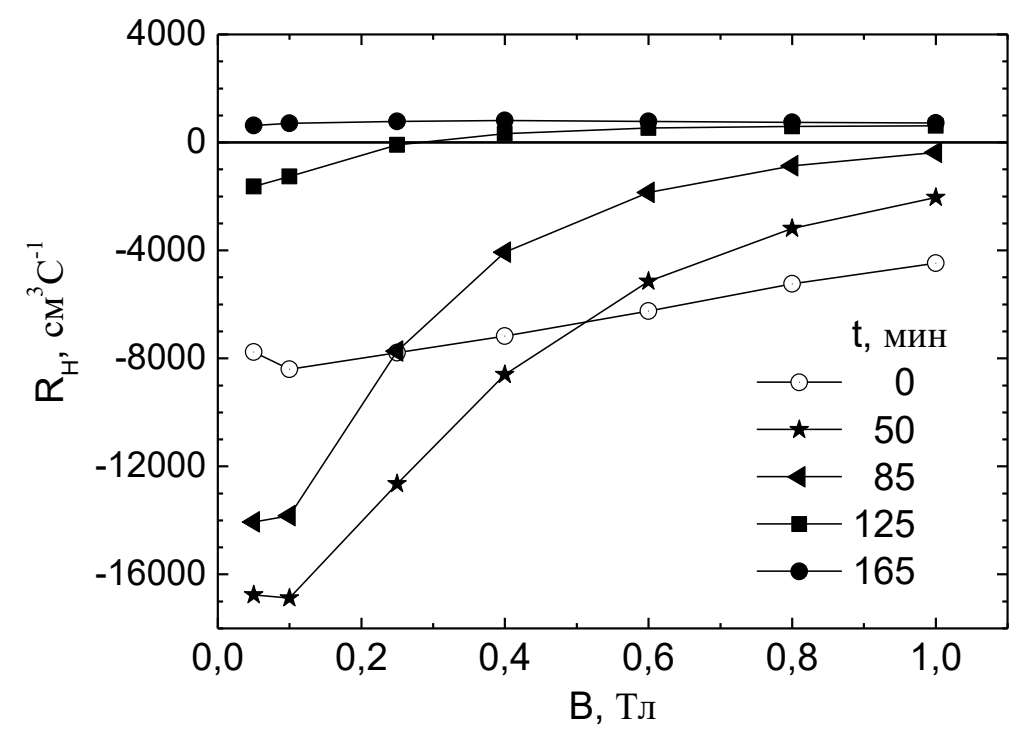

подвижности электронов. Полностью обратная конверсия в ртип проводимости с параметрами, близкими к исходным, произошла после 165 минут хранения при комнатной температуре. Одна из гипотез такого поведения заключается в том, что в процессе плазмохимического травлении скорость травления образца больше или сравнима со скоростью диффузионного фронта междоузельной ртути $\left(\mathrm{Hg}_{\mathrm{I}}\right)$, образовавшейся на поверхности в процессе травления. В результате, в образце у поверхности не происходит значительное накопления $\mathrm{Hg}_{\mathrm{I}}$ до момента остановки травления. После остановки травления и нагрева образца до комнатной температуры, $\mathrm{Hg}_{\mathrm{I}}$ диффундирует вглубь образца, формируя n-слой. Наблюдаемая релаксация и обратная конверсия типа проводимости, по всей видимости, обусловлена рекомбинацией неравновесной $\mathrm{Hg}_{\mathrm{I}}$ с вакансиями ртути и испарением ртути с поверхности образца. Другими словами, образовавшихся вблизи поверхности атомов междоузельной ртути, недостаточно для заполнения заметного количества вакансий ртути, являющихся акцептором, во всем объеме, и для заметного изменения концентрации дырок, находящейся на уровне $10^{16} \mathrm{~cm}^{-3}$. Другая гипотеза, наблюдаемого явления, заключается в распаде сформированных в процессе травления донорных комплексов. В докладе обсуждаются возможные механизмы образования и типы донорных комплексов. 